\title{
The loyalty of Muslim customers on the Indonesian Islamic banks: the role of corporate image, satisfaction, and trust
}

\author{
Baziedy Aditya Darmawan \\ Department of Management, Universitas Islam Indonesia, Yogyakarta, Indonesia \\ e-mail: baziedy@uii.ac.id
}

\begin{abstract}
This study aims to investigate the factors that affect the loyalty of Muslim customers in Indonesian Islamic banking industry. Based on the literature review, this study uses customer satisfaction, corporate image, and customer trust as variables that are expected in affecting the loyalty of Muslim customers. Data collection was conducted through a survey that involved 274 Muslim customers. The model was tested using hierarchical regression. The results show that customer's satisfaction and customer's trust have an important role to build Muslim customers loyalty in Indonesia Islamic banking industry. Furthermore, the results show that customer's trust function as a mediator role (partially) for the relationship of customer satisfaction and customer loyalty.
\end{abstract}

Keywords: loyalty, image, satisfaction, Muslim customer, Islamic banking, Indonesia

\begin{abstract}
Abstrak
Penelitian ini bertujuan untuk menganalisis faktor-fakor yang mempengaruhi loyalitas nasabah Muslim pada industri perbankan syariah di Indonesia. Berdasarkan studi literatur, penelitian ini menggunakan konstruk kepuasan nasabah, citra perusahaan, dan kepercayaan nasabah sebagai variabel yang diduga mempengaruhi loyalitas nasabah Muslim. Pengambilan data dilakukan melalui survei dengan melibatkan 274 nasabah Muslim. Pengujian model dilakukan menggunakan motode regresi bertingkat. Hasil penelitian menunjukkan bahwa kepuasan nasabah dan kepercayaan nasabah merupakan faktor penting dalam mempengaruhi loyalitas nasabah Muslim pada industri perbankan syariah di Indonesia. Penelitian ini juga menemukan bahwa kepercayaan nasabah merupakan variabel yang memediasi pengaruh kepuasan nasabah terhadap loyalitas nasabah.
\end{abstract}

Kata Kunci: loyalitas, citra, kepuasan, kepercayaan, nasabah Muslim, perbankan syariah, Indonesia JEL: M310 DOI: 10.20885/jsb.vol22.iss2.art2

\section{Introduction}

One of the most popular constructs that has been studied in the field of management and business in various industries in many countries is customer loyalty (Tabrani et al., 2018). This is very relevant, considering that customer loyalty is a very important factor for companies to survive (Kassim \& Abdullah, 2010). In the context of Islamic banking industry, customer loyalty has been attracting global researchers in recent decades. This phenomenon is driven by the growing popularity of Islamic Principles implementation in the banking industry on the global scale.

In a country with a Muslim majority like Indonesia, the loyalty of Islamic banking customers is very interesting to be studied. In the customer point of view, the Islamic banking system is typically attracting for Muslim customers. Every Muslim customer utilizes the services of Islamic bank in order to obey the Islamic principles regarding the bank transactions.

Generally, an Islamic bank is the bank that operated based on Islamic Principles. They will develop their services as long as it is allowed and not prohibited by Islamic Principles. Interest is the main issue that prohibited by Islamic principles because it is unfair to take the interest before the economic activity was completed (Hoq et al., 2010). Theoretically, when people doing business, they 
will not only have a potential profit but also risk to get the loss as well. According to Siddiqui (1983), Islamic Principles are concerned to disallowed banks to gain the profit when their customers have a risk to get loss. Hence, as the manifestation of fairness, the Islamic banking system is based on the profit sharing after the economic activity was completed.

As a Muslim-majority country, Indonesia has a big potential market for Islamic banking development. Based on the Islamic banking Statistics published by the Financial Services Authority (OJK), the total assets of Islamic banking in Indonesia has increased by more than 30\% since 2014 to 2017 (ojk.go.id). Nevertheless, the market of Islamic banking in Indonesia is still small, ie 5,3\% compared to all of the national bank industry (setkab.go.id). This phenomenon shows that the Muslim community in Indonesia might prefer to use the financial services provided by conventional banks rather than Islamic banks. This data is contrary to the notion of Amin et al. (2013) that perceive that Islamic banks should able to attract the main segment, ie. Muslim costumers who need to fulfill their religious obligations. In this context, Islamic banking in Indonesia should be able to attract Muslim customers to enhance the growth of the industry market share.

In the term of business, trust is the key to developing sustainable relationships between business and customers (Singh and Sirdeshmukh, 2000). According to Morgan and Hunt (1994), trust will exist when a party believed with the reliability and the integrity of the product provided by the other party. The customer's trust in the bank industry is related to the image of the Bank. According to Flavian et al. (2005), corporate image is an important factor affecting the trust of bank customers.

Moreover, when customers have trust in a brand, it will build a positive attitude toward the brand. In this case, trust is an important factor that builds customer loyalty (Morgant and Hunt, 1994; Lau and Lee, 1999; Sirdeshmukh et al, 2002). Furthermore, some previous studies found that customer loyalty of Islamic Bank is affected by customer satisfaction (Hoq et al., 2010; Amin et al. 2011; Hafeez \& Muhammad, 2012; Amin et al.2013; Saeed et al. 2014).

The issue of trust in Islamic banking is about the compliance of its services with Islamic principles. The level of customer trust is relevant with the promise of Islamic banking to the customers as their image. Trust is also an important factor that plays a role in enhancing customer loyalty. On the other hand, customer satisfaction is relevant to brand image and customer loyalty. Even though the relationship between customer satisfaction, image, trust, and customer loyalty is well established, but there is still limited explanation provided to reveal the relationship of those variables in the context of Islamic banking, particularly for Muslim customers in Indonesia. Therefore, this study investigates customer satisfaction and corporate image with their effect on trust and customer loyalty in Indonesian Islamic banking.

\section{Literature Review and Hypotheses}

\section{Customer Satisfaction, Image, and Trust}

Customer satisfaction means that the customer is well contented with the services provided by a company (Johnson and Fornell, 1991; Saeed et al., 2014). It means that the service performance that is provided by a company is able to meet the costumer expectation (Oliver, 1997). Customer satisfaction is a key factor for every company to grow and compete in the industry. Therefore, Islamic banks need to satisfy their customers in order to attract new customers (Hassan et al., 2008) to enhance the industry growth.

Trust is defined as customer confidence in the quality and reliability of the services offered by the company (Garbarino and Johnson,1999). According to Morgan and Hunt (1994), trust will exist if the customer has the confidence to engage in a relationship with a credible party. It can be concluded that trust is the customer confidence of quality services provided by a company. In the context of Islamic banking, trust means the customer confidence in the compliance of Islamic principle by Islamic banks when providing the services. The compliance with Islamic principles is a pillar that must be maintained in running Islamic banking business that based on the customer's trust (Kayed 
and Hassan, 2011). In the Islamic banking industry, the corporate's capability to satisfy their customers could increase the customer's trust toward various services provided by Islamic Banks. Amin et al. (2013) found that customer satisfaction has positively affected the Muslim customer's trust in the Islamic banking industry.

H1: In Indonesia Islamic banking industry, customer satisfaction will positively affect customer's trust.

Image is an assumption of a person in perceiving a certain characteristic of thing. In the business context, the image is the things that are considered to be associated by the customers when they hear a product or the name of a business organization (Flavian et al., 2004; Nguyen and Leclerc, 2011). At company's point of view, image is defined as a perception of what the company reflects in the customer's mind (Keller,1993).

Furthermore, Kennedy (1977) explained that image has two main components, called functional and emotional. Functional component related to the dimensions of physical evidence (tangible) that can be easily identified and measured, while the emotional component deals with the psychological aspects embodied by individual experience and firm behavior. Therefore, it can be concluded that corporate image is the result of a set of interaction processes between corporate and customer, the customer's knowledge of the firm, the customer's trust, the customer's experience, and deals with the various attributes that differentiate a corporate with the others (Bravo et al., 2009; Hsiong-Ming et al., 2011).

Some previous studies showed that image has been a major factor that forming customer's trust (Ba, 2001; Mukherjee and Nath, 2003; Flavian et al., 2005; Hoq, 2010). Ba (2001) illustrates the effect of image on trust as though the customer feels unwilling to commit to the bank when they consider that the bank doesn't have a good reputation. Flavian et al. (2005), found the relationship between corporate image and trust in both, traditional and online banking, the result showed that bank image has an important role in the forming of customer's trust. Furthermore, Mukhrejee and Nath (2003), reveals that corporate image is a major factor in trust. Hoq (2010) also found that Islamic banking corporate image is positively correlated with customer's trust. In the context of Muslim customers, Amin et al. (2013) reveal that Islamic banking image has a significant positive effect on trust for Muslim customer.

H2: In Indonesia Islamic banking industry, company's image will positively affect customer's trust.

\section{Customer Satisfaction, Image, and Loyalty}

Customer loyalty is a commitment of a customer to repurchase or to subscribe to a preferred product or service in the future, it will affect the repetition of a purchase on a particular product and not affected by any situation that could lead the customer to switch with the other product or service (Oliver,1997). Loyalty has two dimensions, the first is behavioral loyalty that refers to the behavior of the customer to make a purchase because they like a particular brand or service. The second is attitudinal loyalty, that is when customer repurchase activities are performed by emotional and psychological basis (Reichheld, 1993). In this study, customer loyalty refers to the attitude of Muslim customer's loyalty that sustainable over time as a form of adherence to Islamic principles.

A long-term relationship between customers and business organization is stemmed from satisfaction as an important factor (Dagger and O'Brien, 2010). Some previous studies reveal that customer satisfaction has a positive impact on customer loyalty (Zeithaml et al., 1996; Bloemer et al., 1998; Nguyen and LeBlanc, 1998; Cronin et al., 2000, Hafeez and Muhammad, 2012). In the Islamic Banking Industry, satisfied Muslim customers have a tendency to involved in long-term relationships with their banks (Hoq et al., 2010; Amin et al., 2013).

Furthermore, Nguyen and LeBlanc (1998) found that there is a significant relationship between company's image and customer loyalty. Amin et al. (2013) also found that company's image in the Islamic banking industry has a positive effect on customer loyalty for Muslim customers. In the 
context of the Islamic banking industry in Indonesia, it can be assumed that the more religious the image perceived by customers, the more the loyalty of Muslim customers.

H3: In Indonesia Islamic Banking Industry, customer satisfaction will positively affect customer loyalty.

H4: In Indonesia Islamic banking industry, company’s image will positively affect customer loyalty.

\section{Customer Satisfaction, Image, Trust, and Loyalty}

In the service industry, when customers trust a brand, they tend to have a positive behavior toward the brand (Nguyen and Leclerc; 2011). Thus, trust becomes a very important factor in developing customer loyalty (Zeithaml et al., 1996; Castaneda, 2011; Kaur et al., 2012). The relationship between customer and Islamic banking has a religious aspect. Metwally (1996) explained that customers relationship with Islamic banking exists because the customers believe that Islamic banks comply with the Islamic Principles. This religious aspect is the main factor of Muslim customer consideration in choosing bank services. Hegazy (1995) found that religion is the main factor considered by customers to choose Islamic Banks in Egypt. Previous studies found that there is a positive relationship between customer trust and customer loyalty in the Islamic banking industry (Hoq et al., 2010; Amin et al., 2013).

H5: In Indonesia Islamic banking industry, customer trust will positively affect customer loyalty.

In addition, several previous studies found that customer trust has a role in mediating the effect of customer satisfaction and corporate image on customer loyalty. Ball et al. (2004) found that corporate image has an indirect effect on customer loyalty through customer's trust. Furthermore, Brunner et al. (2008) found that customer's trust has a role in mediating the relationship between corporate image and customer loyalty. Meanwhile, Dimitriadis et al. (2011) state that a high level of trust may affect a satisfied customer to be a loyal customer. Moreover, Kassim and Abdullah (2010) found that there was a significant relationship between customer trust and customer loyalty.

H6: In Indonesia Islamic banking industry, customer's trust mediates the relationship between corporate image and customer loyalty.

H7: In Indonesia Islamic banking industry, customer's trust mediates the relationship between customer satisfaction and customer loyalty.

\section{Research Methods}

A survey was conducted by involving Muslim customers in Indonesia specifically. There are two types of Islamic bank in Indonesia, first is an independent Islamic bank with the basis of Islamic principles that prohibit them from taking or giving interest and doing non-halal activities. The second is Islamic bank that operated at the same roof with the conventional one as the Islamic business unit that is also well known as Islamic bank window. The respondents of this study are Indonesian Muslim customers of both types.

A non-probability model was used in this study with the convenience sampling as the technique. The questionnaire was distributed to the respondent that chosen by the easiness to contact through an online platform. A total of 274 respondents had filled out a complete questionnaire, consisting of $53 \%$ of men and $46.72 \%$ of women. Based on age characteristics, the majority of respondents is above 35 years $(36 \%)$, while on the educational background characteristics, the majority of respondents is undergraduate $(61 \%)$. Furthermore, the majority of respondents that work as private employees (51\%). Table 1 below shows the profile of respondents based on the demographic characteristics.

Table 2 shows that the questionnaire was developed by adapting various suggested indicators and widely used by previous researchers with totally 13 indicators which are used to measure 4 variables. Customer satisfaction was measured by adapting the scale developed by Fornell et al. (1996) and Levesque and McDougall (1996); image was measured by adapting the indicator scale as 
suggested by LeBlanc and Nguyen (1996) and Flavian et al. (2004); trust indicators was adapted from the scale that developed by Flavian et al. (2005) and Othman and Owen (2002); and customer loyalty is measured by adapting the item scale from Zeithaml et al. (1996).

The questionnaire was developed with a five-point Likert scale to measure the customer perceptions of image, trust, and customer loyalty which ranging from "strongly disagree" (1) to "strongly agree (5)". While measurement of customer satisfaction was used ranging from "very unsatisfied" (1) to "very satisfied" (5). The validity test was used to assess the relevance and how well each item measures a construct. The reliability test was used to test the consistency of the instrument measurement. A consistent instrument has consistent results if it used repeatedly at different times.

Table 1. The respondent's demographic profile.

\begin{tabular}{lr}
\hline Demographic characteristics & Frequency $(\%)$ \\
\hline Gender & 53 \\
Male & 47 \\
Female & \\
Age & 16 \\
$<20$ years old & 22 \\
$20-24$ years old & 26 \\
$30-34$ years old & 36 \\
$>35$ years old & \\
& \\
Education & 17 \\
Senior high school & 8 \\
Diploma & 61 \\
Undergraduate & 14 \\
Postgraduate & \\
& \\
Occupation & 11 \\
Student & 51 \\
Private employee & 7 \\
Entrepreneur & 11 \\
Civil servant & 14 \\
State-owned enterprise employee & 6 \\
Others & \\
\hline
\end{tabular}

Table 2. Variable's Measurement Development

\begin{tabular}{llc}
\hline Variables & References & Items \\
\hline Customer satisfaction & Adapted from Fornell et al. (1996) and Levesque and McDougall (1996) & 3 \\
Corporate image & Adapted from LeBlanc and Nguyen (1996) and Flavian et al. (2004) & 3 \\
Customer's trust & Adapted from Flavian et al. (2005) and Othman and Owen (2002) & 3 \\
Customer loyalty & Adapted from Zeithaml et al. (1996) & 4 \\
\hline
\end{tabular}

Table 3 shows the results of the validity and reliability test of the instruments for customer satisfaction, image, trust, and customer loyalty variables. A bivariate correlation was used to test the correlation of each indicator to the total score on the constructs, and the result was significant for all items, so it can be concluded that all items were valid. The Cronbach's Alpha was used to test the reliability of each variable. The Cronbach's Alpha coefficient for each variable exceeds the minimum standard of 0.70 . It is indicated that the instrument provided a good consistency and reliability. The coefficient of Cronbach's Alpha obtained of 0,833 (customer satisfaction), 0.844 (image), 0.848 (trust), and 0,850 (customer loyalty). The test of validity and reliability result for all item in the questionnaire are consistent with the previous studies (Hoq et al., 2010 \& Amin et al. 2013). There 
are valid results for each item and reliable results for each variable.

Table 3. Validity and Reliability for The Measurements

\begin{tabular}{lcc}
\hline Variables & Correlation & $\alpha$ \\
\hline Customer Satisfaction & 0,835 & 0,833 \\
I am satisfied with the employee's response and prompt services & 0,847 \\
I am satisfied with financial services advice & 0,791 \\
I am satisfied with the products and services provided by my bank & \\
& \\
Image & 0,886 & 0,844 \\
Islamic banks have competent and efficient staff reputation & 0,874 \\
Islamic banks image & 0,797 \\
Islamic banks offer attractive products and services & \\
& \\
Trust & 0,873 \\
Islamic banks are truly concerned with Islamic Principles & 0,848 \\
I believe that deposits in Islamic banks are safe & 0,882 \\
I believe the products and services offered are based on Islamic Principles & 0,821 \\
Customer Loyalty & \\
Customers intention to say positive things about Islamic banks to other people & 0,975 \\
Willingness to recommend family and relatives to do business with Islamic banks & 0,859 \\
Recommend Islamic banks to someone who seeks advice & 0,961 \\
Continue to do more business with Islamic banks & 0,907 \\
\hline
\end{tabular}

This study uses SPSS to estimate both, the main and mediation effects stated in the hypotheses. Hypotheses testing is conducted using a hierarchical model, namely a type of linear regression models in which the test fall into a hierarchical way. In this hierarchical model, some linear regression is carried out in stages by adding more predictors, such as demographic control variables and other desired predictors (Sweet \& Grace-Martin, 2011).

This study divides the hierarchical model into three stages. At the first stage, multiple linear regression is used to test the effect of customer satisfaction and corporate image on customer's trust. At this stage, the model consists of three variables to test whether $\mathrm{H} 1$ and $\mathrm{H} 2$ could be accepted or rejected. At the second stage, another multiple linear regression was conducted to test the effect of customer satisfaction and corporate image on customer loyalty. In this stage, the results will be used to investigate whether $\mathrm{H} 3$ and $\mathrm{H} 4$ can be accepted or rejected. At the last stage, a multiple linear regression involves customer 's trust in addition to customer satisfaction and corporate image as an independent variable to customer loyalty to test $\mathrm{H} 5, \mathrm{H} 6$, and $\mathrm{H7}$. All multiple linear regression tests were carried out twice at each stage by adding demographic control variables as shown in Table 6.

Table 4. Correlation among Variables

\begin{tabular}{lrrrrrrrrrr}
\hline & Mean & \multicolumn{1}{c}{ SD } & \multicolumn{1}{c}{1} & \multicolumn{1}{c}{2} & 3 & 4 & 5 & 6 & \multicolumn{1}{c}{7} \\
\hline 1 Customer Loyalty & 15.79 & 0.937 & 1 & & & & & & & \\
$\quad$ Customer & 11.74 & 1.090 & 0.632 & 1 & & & & & \\
2 Satisfaction & & & & & & & & & \\
3 Corporate Image & 11.80 & 1.259 & 0.538 & 0.784 & 1 & & & & \\
4 Customer's Trust & 11.79 & 1.209 & 0.559 & 0.730 & 0.882 & 1 & & & \\
5 Gender & 0.47 & 0.500 & 0.032 & 0.038 & 0.042 & 0.040 & 1 & & \\
6 Age & 1.82 & 1.091 & -0.049 & 0.028 & 0.005 & -0.012 & 0.076 & 1 & \\
7 Education & 1.72 & 0.909 & 0.011 & 0.085 & 0.099 & 0.099 & 0.084 & -0.067 & 1 & \\
8 Occupation & 1.84 & 1.466 & -0.012 & -0.122 & -0.091 & -0.040 & -0.052 & -0.094 & -0.043 & 1 \\
\hline
\end{tabular}


Table 5. The Differences of Customer Trust and Customer Loyalty based on Demographic Profiles

\begin{tabular}{lcccc}
\hline \multirow{2}{*}{ Variables } & \multicolumn{2}{c}{ Customer Trust } & \multicolumn{2}{c}{ Customer Loyalty } \\
\cline { 2 - 5 } & \multicolumn{2}{c}{ Mean } & Sig & \multicolumn{2}{c}{ Mean } & Sig \\
\hline Gender & 11.86 & 0.285 & 16.78 & 0.572 \\
Male & 11.87 & & 16.88 & \\
Female & & & & \\
Age & 11.98 & 0.039 & 16.73 & 0.239 \\
$<20$ years old & 11.58 & & 16.45 & \\
20-26 years old & 12.06 & & 16.81 & \\
27-34 years old & 11.85 & & 17.11 & \\
>35 years old & & & & \\
& & & & \\
Education & 11.72 & 0.084 & 16.91 & 0.487 \\
Senior high school & 11.95 & & 17.23 & \\
Diploma & 11.86 & & 16.87 & \\
Undergraduate & 12.03 & & 16.29 & \\
Postgraduate & & & & \\
Occupation & 12.06 & 0.050 & 17.19 & 0.828 \\
Student & 11.91 & & 16.80 & \\
Private employee & 11.67 & & 16.94 & \\
Entrepreneur & 11.74 & & 16.84 & \\
Civil servant & 11.74 & & 16.87 & \\
State-owned enterprise employee & 11.88 & & & \\
Others & & & & \\
\hline
\end{tabular}

Table 6. The Results of Hierarchical Regression

\begin{tabular}{|c|c|c|c|c|c|c|c|c|c|c|c|c|}
\hline & \multicolumn{4}{|c|}{$\begin{array}{c}\text { Model (Step) } 1 \\
\text { Customer's Trust }\end{array}$} & \multicolumn{4}{|c|}{$\begin{array}{c}\text { Model (Step) } 2 \\
\text { Customer's Loyalty }\end{array}$} & \multicolumn{4}{|c|}{$\begin{array}{c}\text { Model (Step) } 3 \\
\text { Customer's Loyalty }\end{array}$} \\
\hline & Estimate & $\mathrm{t}$ & Estimate & $\mathrm{t}$ & Estimate & $\mathrm{t}$ & Estimate & $\mathrm{t}$ & Estimate & $\mathrm{t}$ & Estimate & $\mathrm{t}$ \\
\hline $\begin{array}{l}\text { Customer } \\
\text { Satisfaction }\end{array}$ & $\begin{array}{r}0.110^{* *} \\
(0.051)\end{array}$ & 2.160 & $\begin{array}{r}0.117 * * \\
(0.051)\end{array}$ & 2.292 & $\begin{array}{r}0.470 * * * \\
(0.065)\end{array}$ & 7.230 & $\begin{array}{r}0.481 * * * \\
(0.065)\end{array}$ & 7.379 & $\begin{array}{r}0.445 * * * \\
(0.065)\end{array}$ & 6.885 & $\begin{array}{r}0.455^{* * *} \\
(0.065)\end{array}$ & 7.010 \\
\hline $\begin{array}{l}\text { Corporate } \\
\text { Image }\end{array}$ & $\begin{array}{r}0.772 * * * \\
(0.044)\end{array}$ & 17.550 & $\begin{array}{r}0.770 * * * \\
(0.044)\end{array}$ & 17.439 & $\begin{array}{r}0.081 \\
(0.056)\end{array}$ & 1.441 & $\begin{array}{r}0.081 \\
(0.056)\end{array}$ & 1.443 & $\begin{array}{r}-0.094 \\
(0.081)\end{array}$ & -1.164 & $\begin{array}{r}-0.086 \\
(0.081)\end{array}$ & -1.062 \\
\hline $\begin{array}{l}\text { Customer's } \\
\text { Trust }\end{array}$ & & - & & & & & & & $\begin{array}{r}0.227 * * \\
(0.077)\end{array}$ & 2.967 & $\begin{array}{r}0.218^{* *} \\
(0.077)\end{array}$ & 2.825 \\
\hline Gender & & & $\begin{array}{r}0.013 \\
(0.069)\end{array}$ & 0.183 & & & $\begin{array}{r}0.034 \\
(0.089)\end{array}$ & 0.389 & & & $\begin{array}{r}0.032 \\
(0.087)\end{array}$ & 0.362 \\
\hline Age & & & $\begin{array}{r}-0.016 \\
(0.032)\end{array}$ & -0.500 & & & $\begin{array}{r}-0.055 \\
(0.041)\end{array}$ & -1.360 & & & $\begin{array}{r}-0.052 \\
(0.040)\end{array}$ & -1.291 \\
\hline Education & & & $\begin{array}{r}0.015 \\
(0.038)\end{array}$ & 0.383 & & & $\begin{array}{l}-0.053 \\
(0.049)\end{array}$ & -1.080 & & & $\begin{array}{r}-0.056 \\
(0.048)\end{array}$ & -1.160 \\
\hline Occupation & & & $\begin{array}{r}0.038 \\
(0.024)\end{array}$ & 1.591 & & & $\begin{array}{r}0.038 \\
(0.030)\end{array}$ & 1.253 & & & $\begin{array}{r}0.030 \\
(0.030)\end{array}$ & 0.990 \\
\hline Adj $R^{2}$ & 0.78 & & 0.77 & & 0.400 & & 0.401 & & 0.41 & & 0.417 & \\
\hline $\mathrm{F}$ & 483.595 & $F * *$ & 161.1 & & $91.875^{*}$ & & $31.519 *$ & & $65.948^{\circ}$ & & $28.862 *$ & \\
\hline $\mathrm{df}$ & 273 & & 273 & & 273 & & 273 & & 273 & & 273 & \\
\hline $\mathrm{n}$ & 274 & & 27 & & 274 & & 274 & & 274 & & 274 & \\
\hline
\end{tabular}

Note: Numbers in parentheses are standard error, and *,**, and *** denote significance level on $10 \%, 5 \%, 1 \%$, respectively.

\section{Results and Discussion}

\section{Customer Satisfaction, Image, and Trust.}

Table 6 shows the Adjusted R square value of the first model, namely customer satisfaction, corporate image, and customer's trust with the value of 0.781 . It means that as much as $78.1 \%$ of the variation of the variable customer's trust can be measured by customer satisfaction and corporate image variables, 
while the rest was explained by other factors outside our model. The value of estimate for customer satisfaction and corporate image are both positive. It means that customer satisfaction and corporate image have a positive effect on customer's trust. However, company's image has a greater effect $(0.772)$ than customer satisfaction (0.110) in building customer's trust. Furthermore, the effect of company's image on customer's trust is significant at the level of $p<0.01$, while the effect of customer satisfaction on customer's trust is significant at the level of $\mathrm{p}<0.05$, therefore $\mathrm{H} 1$ and $\mathrm{H} 2$ are accepted.

A significant positive effect between customer satisfaction and customer's trust means that Muslim customer's trust in Indonesia Islamic banking industry is affected by how satisfied they are with perceived services provided by the banks. These results are consistent with the Amin et al. (2013) who found that the satisfaction of Muslim customers in the Malaysian Islamic banking industry positively affected the customer's trust. These results are very relevant considering the culture and behavior of both, Muslim customers in Indonesia and Malaysia that maybe not much different. This finding emphasizes that the ability of Islamic banks in Indonesia to satisfied Muslim customers is one of an important factor in building their trust.

Company's image also has a positive effect on customer's trust significantly. This result is consistent with previous studies that also used the samples of Muslim customers in the Islamic banking industry (Hoq et al., 2010; Amin et al., 2013). Table 6 reveals that company's image has a greater effect in building customer 's trust rather than customer satisfaction, this result is consistent with the results of Ba (2001), Mukherjee and Nath (2003), Flavian et al. (2005), and Hoq (2010). Amin et al. (2013) explain that corporate image in the Islamic banking industry is relatively easy to convert as a trust for customers. This finding is also able to explain that company's image is not only a major factor in developing trust in the conventional bank industry (Flavian et al., 2005) but also in the Islamic banking industry. Corporate image is an important factor for Islamic banks in sustaining their market positions (Hoq et al, 2010). Therefore, Islamic banks in Indonesia need to build a good image to provide values for Muslim customers in order to develop trust and maintain long-term relationships with them trough competent employees and attractive banking products.

\section{Customer Satisfaction, Image, and Loyalty}

As shown in Table 6, the R square value of the second model, namely customer satisfaction, corporate image, and customer loyalty with the value of 0.400 . It means that as much as $40 \%$ variation of customer loyalty can be measured by customer satisfaction and corporate image, while the rest was explained by other factors outside this research. Table 6 shows the value of estimate for customer satisfaction and corporate image are both positive, it means that customer satisfaction and customer's trust have a positive effect on customer loyalty. Customer satisfaction has a greater effect $(0.470)$ than corporate image (0.081) in building customer loyalty. Furthermore, the effect of customer satisfaction on customer loyalty is significant at the level of $p<0.01$, while the effect of company's image on customer loyalty is not significant, therefore $\mathrm{H} 3$ is accepted, but H4 is rejected.

This study found that customer satisfaction has a significant positive effect on customer loyalty. It means that the loyalty of Muslim customers in Indonesia Islamic banking industry is affected by how satisfied they are with the services provided by the bank. This finding supports Dagger and O'Brien (2010) who explain that one of the main factors for business organizations to build long-term relationships with customers is customer satisfaction. This finding is also consistent with several previous studies (Zeithaml et al., 1996; Bloemer et al., 1998; Nguyen and LeBlanc, 1998; Cronin et al., 2000, Hafeez and Muhammad, 2012). Furthermore, in the context of the Islamic banking industry, this finding is consistent with several previous studies which explain that customer satisfaction is an important factor in building customer loyalty (Hoq et al., 2010; Amin et al. 2011; Hafeez \& Muhammad, 2012; Amin et al. 2013; Saeed et al. 2014).

Based on this finding, the dimension of customer satisfaction has a significant role in building the loyalty of Muslim customers in Indonesian Islamic banking. It means that the willingness of Muslim customers in Indonesia Islamic banking industry to build a long-term relationship and 
The loyalty of Muslim customers on the Indonesian Islamic banks: the role of corporate image, satisfaction and trust

recommend Islamic banks to others is influenced by how satisfied they are with the services of Islamic banks. In consequence, Islamic banks in Indonesia must be able to satisfied customers in order to guarantee long-term relationships with Muslim customers. According to Hoq et al. (2010) and Amin et al. (2013), a satisfied Muslim customer has a tendency to be involved in long-term relationships with Islamic banks. However, this also means that if Muslim customers feel dissatisfied, then they might discontinue their relationship with Islamic banks, therefore Islamic banks in Indonesia must be able to provide services that are able to satisfy Muslim customers.

\section{Customer Satisfaction, Image, Trust, and Loyalty}

Table 6 shows the R square value of the third model, namely customer satisfaction, corporate image, customer's trust and customer loyalty with the value of 0.416 . It means that as much as $41.6 \%$ variation of customer loyalty variable can be measured by customer satisfaction, corporate image, and customer's trust, while the rest was explained by other factors outside this research. The value of estimate for customer satisfaction (0.445) and customer's trust (0.227) are both positive, it means that customer satisfaction and customer's trust have a positive effect on customer loyalty. Nevertheless, the value of estimate for company's image is negative (-0.094), it means that corporate image has a negative effect on customer loyalty after customer's trust included in this third model. Furthermore, the effect of customer's trust on customer loyalty is significant at the level of $p<0.05$, while the effect of company's image on customer loyalty still not significant after including customer's trust in the third model, thus H5 is accepted, but H6 is rejected.

This study found that customer trust has a significant positive effect on customer loyalty, it means that the loyalty of Muslim customers in Indonesia Islamic banking industry is also affected by how trusting they are with the compliance of Islamic bank to Islamic principles. This finding is consistent with several previous studies, that is when customers have trust in a brand, they will tend to behave positively toward the brand (Nguyen and Leclerc; 2011), therefore trust has an important role in building customer loyalty (Zeithaml et al., 1996; Castaneda, 2011; Kaur et al., 2012). In the context of the Islamic banking industry, this finding is consistent with previous studies conducted by Hoq et al. (2010) and Amin et al. (2013) who found that there is a significant positive effect between customer trust on customer loyalty in the Malaysia Islamic banking industry.

This finding confirms that the relationships between Muslim customers and Islamic banks comprise a religious aspect. The willingness of Muslim customers to build relationships with the Islamic banks is affected by customer trust that Islamic banks complied with Islamic principles (Metwally, 1996) or in other words, the aspect of adherence to Islamic principles is considered by Muslim customers in choosing banking services (Hegazy, 1995). It means that when Muslim customers believe that Islamic banks comply with the Islamic principles, they will tend to be loyal customers.

The religious aspects of Muslim customers regarding loyalty in the Islamic banking industry are very relevant. According to Hoq et al. (2010), in building relationships with the Islamic banks, Muslim customers not only feel the financial benefit but also the spiritual benefits that are fulfilled as a manifestation of Muslim adherence to Islamic principles. Consequently, Islamic banks in Indonesia should build the trust of Muslim customers, not only through good service performance but also through the ability to convince Muslim customers that all operational activities of the banks comply with the Islamic principles. Islamic banks in Indonesia should guarantee that every service provided are free and protected from interest (riba), uncertainty (gharar), and gambling (maisyir) in order to build long-term relationships with Muslim customers.

As shown in table 6, customer satisfaction has positive significant effect on customer loyalty (model $2, \beta=0.470$ ) and customer's trust (model $1, \beta=0.117$ ), which also positively affect customer loyalty (model $3, \beta=0.445$ ). Comparing Models 2 and 3 , this study found that the positive effect of customer satisfaction on customer loyalty in model 2 becomes weaker in model 3 ( $\beta=0.470$ vs. $\beta=$ 0.445 ). Thus, customer's trust partially mediates the relationship between customer satisfaction and customer loyalty, therefore $\mathrm{H7}$ is accepted. 
This finding is consistent with Dimitriadis et al. (2011) which stated that a loyal customer is a satisfied customer who has a high level of trust. Since trust play an important role to build customer loyalty (Kassim and Abdullah, 2010), Islamic banks in Indonesia are not only required to be able to satisfy Muslim customers through prompt and reliable services but also should be able to convince them that the services provided comply with the Islamic principles. This is important to ensure Muslim customers are willing to build long-term relationships with Islamic banks in Indonesia.

\section{Conclusion and Future Direction}

The trust of Muslim customers in Indonesia should be built through the service performance of Islamic banks that are able to provide satisfaction. In addition, the trust of Muslim customers in Indonesia could also be built with a good image, through competent staff and attractive banking products for Muslim customers. The satisfaction and trust of Muslim customers in Indonesia Islamic banking industry also has an important role in building long-term relationships. Muslim customers tend to become loyal if they are satisfied with the services of Islamic banks and have the confidence that all operations of Islamic banks comply with Islamic principles. Hopefully, the results of this study could contribute to the growth of the Islamic banking industry in Indonesia.

However, this study has several limitations that need to be considered. First, the sample in this study only involves Muslim customers. Second, the sample of this study were customers who came from both, full-fledged Islamic banks and dual-window banks (banks with two windows in one roof, conventional banks, and Islamic banks). For this reason, further research could add to the involvement of non-Muslim customers to make a comparison between two types of customer (Muslim and non-Muslim). In addition, further research could also compare the results of interactions between variables on full-fledged Islamic banks and dual-window banks.

\section{References}

Amin, M., Isa, Z. and Fontaine, R. (2011). The role of customer satisfaction in enhancing customer loyalty in Malaysian Islamic banks. The Service Industries Journal, 31 (9), 1519-1532.

Amin, M., Isa, Z. and Fontaine, R. (2013). Islamic banks: Contrasting the drivers of customer satisfaction on image, trust, and loyalty of Muslim and non-Muslim customers in Malaysia. International Journal of Bank Marketing, 31 (2), 79-97.

Ba, S. (2001). Establishing Online Trust Through a Community Responsibility System. Decision Support Systems, 31 (3), 323-336.

Bloemer, J., De Ruyter, K., \& Peeters, P. (1998). Investigating drivers of bank loyalty: The complex relationship between image, service quality and satisfaction. International Journal of Bank Marketing, 16 (7), 276-286.

Bravo, R., Montaner, T. and Pina, J.M. (2009). The role of bank image for customers versus noncustomers. International Journal of Bank Marketing, 27 (4), 315-334.

Castaneda, J. S. (2011). Relationship between customer satisfaction and loyalty on the internet. Journal of Business Psychology, 26 (3), 371-383.

Dagger, T. S. and O'Brien, T. K. (2010). Does Experience Matter? Differences in relationship benefit, satisfaction, trust, commitment and loyalty for novice and experience service users. European Journal of Marketing, 44 (9/10), 1528-1552.

Flavian, C., Torres, E. and Guinaliu, M. (2004). Corporate image measurement: A further problem for the tangibilization of Internet banking services. International Journal of Bank Marketing, 22 (5), 366-384.

Flavian, C., Guinaliu, M. and Torres, E. (2005). The influence of corporate image on consumer trust: 
A comparative analysis in traditional versus internet banking. Internet Research, 15 (4), 447470.

Fornell, C., Johnson, M.D., Anderson, E.W., Cha, J. and Bryant, B.E. (1996). The American customer satisfaction index: nature, purpose and findings. Journal of Marketing, 60 (4), 7-18.

Garbarino, E. and Johnson, M. (1999). The Different Roles of Satisfaction, Trust, and Commitment in Customer Relationships. Journal of Marketing, 63 (2), 70-87.

Hafeez, S. and Muhammad, B. (2012). The Impact of Service Quality, Customer Satisfaction and Loyalty Programs on Customer's Loyalty: Evidence from Banking Sector of Pakistan. International Journal of Business and Social Science, 3 (16), 200-209.

Hassan, A., Chachi, A. and Latiff, S. A. (2008). Islamic Marketing Ethics and Its Impact on Customer Satisfaction in the Islamic Banking Industry. Journal of King Abdulaziz University: Islamic Economics, 21 (1), 27-46.

Hegazy, I. (1995). An Empirical Comparative Study Between Islamic and Commercial Bank's Selection Criteria in Egypt. International Journal of Commerce and Management, 5 (3), 4661.

Hoq, M. Z., Sultana, N. and Amin, M. (2010). The Effect of Trust, Customer Satisfaction and Image on Customers' Loyalty in Islamic Banking. South Asian Journal of Management, 17 (1), 7093.

Hsiong-Ming, L., Ching-Chi, L. and Cou-Chen, W. (2011). Brand image strategy affects brand equity after M \& A. European Journal of Marketing, 45 (7/8), 1091-1111.

Johnson, M. D. and Fornell, C. (1991). A Framework for Comparing Customer Satisfaction across Individuals and Product Categories. Journal of Economic Psychology, 12 (2), 267-286.

Kassim, N. and Abdullah, N.A. (2010). The effect of perceived service quality dimensions on customer satisfaction, trust, and loyalty in e-commerce settings: A cross cultural analysis. Asia Pacific Journal of Marketing and Logistics, 22 (3), 351-371.

Kaur, G., Sharma, R. D. and Mahajan, N. (2012). Exploring customer switching intentions through relationship marketing paradigm. International Journal of Bank Marketing, 30 (4), 280-302.

Kayed, R.N. and Hassan, M.K. (2011). The global financial crisis and Islamic finance. Thunderbird International Business Review, 53 (5), 551-64.

Keller, K. L. (1993). Branding Shortcuts. Marketing Management, 14 (1), 18-23.

Kennedy, S. H. (1977). Nurturing corporate image. European Journal of Marketing, 11 (3), 120-164.

Lau, G. T. and Lee S. H. (1999). Consumer's Trust in a Brand and the Link to Brand Loyalty. Journal of Market Focused Management, 4 (4), 341-370.

LeBlanc, G. and Nguyen, N. (1996). Cues used by customers evaluating corporate image in service firms: an empirical study in financial institutions. International Journal of Service Industry Management, 7 (2), 44-56.

Levesque, T. and McDougall, G. H. G. (1996). Determinants of customer satisfaction in retail banking. International Journal of Bank Marketing, 14 (7), 12-20.

Metwally, M. (1996). Attitudes of Muslims towards Islamic banks in a dual-banking system. American Journal of Islamic Finance, 6 (1), 11-17.

Morgan, R.M. and Hunt, S.D. (1994). The Commitment-Trust Theory of Relationship Marketing. Journal of Marketing, 58, (3), 20-38. 
Mukherjee, A. and Nath, P. (2003). A Model of Trust in Online Relationship Banking. International Journal of Bank Marketing, 21 (1), 5-15.

Nguyen, N. and LeBlanc, G. (1998). The mediating role of corporate image on customers' retention decisions: an investigation in financial services. International Journal of Bank Marketing, 16 (2), 52-65.

Nguyen, N. and Leclerc, A. (2011). The effect of service employees' competence on financial institutions' image: benevolence as a moderator variable. Journal of Services Marketing, 25 (5), 349-360.

Oliver, R. (1997). Satisfaction: A Behavioural Perspective on the Consumer. McGraw Hill. New York.

Othman, A. and Owen, L. (2002). The multi dimensionality of CARTER model to measure customer service quality in Islamic banking industry: a study in Kuwait Finance House. International Journal of Islamic Financial Services, 3 (4), 1-12.

Otoritas Jasa Keuangan. (2017). Statistik Perbankan Syariah. Retrieved from https://www.ojk.go.id/id/kanal/syariah/data-dan-statistik/statistik-perbankansyariah/default.aspx.

Reichheld, F. F. (1993). Loyalty-Based Management. Harvard Business Review, March-April, 64-73.

Saeed, R., Iqbal, A., Lodhi, R. N., Sami, A., Riaz, A., Munir, M., and Mizna. (2014). Impact of Service Quality on Customer Loyalty in Islamic Banking Sector of Pakistan: A Mediating Role of Customer Satisfaction. Journal of Basic and Applied Scientific Research, 4 (2), 135-143.

Sekretariat Kabinet Republik Indonesia. (2017). Meski Institusinya Terbanyak di Dunia, Presiden Jokowi Sebut Pasar Syariah di Indonesia Masih Kecil Sekali. Retrieved from http://setkab.go.id/meski-institusinya-terbanyak-di-dunia-presiden-jokowi-sebut-pasarsyariah-di-indonesia-masih-kecil-sekali/.

Siddiqui, M.N. (1983). Banking Without Interest. The Islamic Foundation, Leicester, U.K.

Singh, J. and Sirdeshmukh, D. (2000). Agency and Trust Mechanism in Customer Satisfaction and Loyalty Judgements. Journal of the Academy of Marketing Science, 28 (1), 150-167.

Sirdeshmukh, D., Singh, J. and Sabol B. (2002). Consumer Trust, Value and Loyalty in Relational Exchanges. Journal of Marketing, 66 (1), 15-37.

Sweet, S.A. \& Grace-Martin, K.A. (2012). Data Analysis with SPSS: A First Course in Applied Statistics ( $4^{\text {th }}$ Edition). Pearson.

Tabrani, M. and Amin, M. (2018). Trust, commitment, customer intimacy and customer loyalty in Islamic banking relationships. International Journal of Bank Marketing. 36 (5), 823-848.

Zeithaml, V. A., Berry, L. L. and Parasuraman, A. (1996). The Behavioural Consequences of Service Quality. Journal of Marketing, 60 (2), 31-46. 